researches which have led to a definite and final conclusion as to the constitution of Saturn's rings, brings the whole work to a fitting termination.

The diagrams and illustrations, though not very numerous, are generally good and clear, with the possible exception of Fig. 23, which seems to need more explanation than is given. The bibliographical notes, which are appended to every chapter, give most valuable and copious reference to the original authorities. Prof. Darwin's book ought to be read by "all those whose minds are in any degree permeated by the scientific spirit" (preface): it is certain to excite the interest and appreciation of all such, and not least of the mathematician, in spite of the fact that there is not a mathematical symbol from one end to the other.

W. E. P.

\section{FLORA OF ROUMANIA.}

Conspectul Florei Romaniei. By Dr. D. Grecescu. Pp. $\cdot x v i+835$. (Bucharest : Tipografiea Dreptatea, I 898.)

7 HIS is a valuable addition to our knowledge of the 1 floras of the Balkan States. Prof. Grecescu's book supersedes Branza's "Prodromul Florei României," which so far has been the only comprehensive work on the flora of Roumania. Branza enumerated 2100 species, of which Grecescu admits 1875 as "good." These figures refer to Roumania, exclusive of Dobrudsha. Grecescu includes, of course, the latter, and records 2450 species besides 550 varieties. This very considerable increase is partly due to the addition of the Dobrudsha flora, partly to the admission of not a few of Schur's very questionable species and of other "species minutæ," but mainly, no doubt, to the more complete collections which were at the author's disposal. The author evidently worked under considerable difficulties. He had not only to accumulate the bulk of the material on which his work rests, but was also obliged at the same time to build up, as it seems, a general herbarium of European plants for comparison. It is only fair to mention this in order that we should not criticise too severely shortcomings which are inevitable under such conditions.

The book consists of two parts, of which the first contains the Conspectus proper, or the enumeration of the species found within the borders of the kingdom of Roumania, preceded by a synoptical table of the classes and orders; whilst the second part deals with the general physiography of the country and the principal vegetations and floras of Roumania. The author follows in the arrangement of the orders on the whole the system adopted in Nyman's "Conspectus Floræ Europeæ." Why he deviates from it in certain cases is difficult to understand, if it is not partly to suit his key of orders; but when he subdivides, for instance, the "Embriogene Dicotyledóne Apetale Unisexuate" (i.e. the unisexual Apetalæ) into "Angiosperme" and "Gymnosperme," including Gnetaceæ in the former, then he shows such a disregard of modern nomenclature and the results of modern taxonomy, that at least an attempt of explanation ought to have been made. In fact, it is always precarious to introduce taxonomic reforms of a NO. I 523 , VOL. 59] higher order into local floras, and the author would have done far better if he had stuck right through to Nyman's "Conspectus."

The introductory chapters of the first part ("Clasificatiea generală" and "Dispositiea familiilor naturale") are altogether the weakest part of the work, and might have been just as well omitted as being outside the scope of the book. The same applies to the short diagnoses of the tribes, subgenera and more subordinate groups which are dispersed through the enumeration of the species. As neither the genera nor the species are diagnosed, the result is an imperfect key which is useless to the beginner who does not know the genera, whilst the more advanced student who knows them is equally puzzled, as it does not carry him far enough.

The terminology is sometimes rather loose; for instance, when the perianth of Plumbaginea and Primulaceæ is described as "herbaceous," or the terms used are obsolete, e.g. when "perisperm" is applied, as it was originally by Jussieu to albumen generally. Other errors, asi the description of the capsules of Primulaceæ as pyxidia generally, are evidently mere slips. On the other hand, innovations like the subdivision of Gramineæ in two tribes, Eugraminex and Maydea, are quite unjustifiable.

The author distinguishes three principal zones of vegetation in Roumania, i.e. an Alpine zone, a forest zone and a steppe zone, and he considers Roumania as forming part of a greater and natural phytogeographical region, the region of the Flora Dacica, with the Southern Carpathians as the principal focus, and extending to the Theiss in the west, the Dniester in the east, and the Danube and the Black Sea in the south and south-east. This section of the book is of considerable interest, and it is to be regretted that the author has not accompanied it by a résumé in French, English or German. We are sure there are many botanists who are interested in the constitution and differentiation of the Roumanian flora, but to whom a book written in Roumanian does simply not exist. They would certainly be thankful if the author would publish a translation or a comprehensive abstract of the second part of his book in one of the languages mentioned. Either, we venture to suggest, would gain very much by a careful revision which will convince him that, for instance, the number of endemic species admitted in the Alpine zone of the Flora Dacica (fully 3I per cent. !) is far too high, or that many of the so-called Mediterranean elements can hardly claim this designation.

O. STAPF.

\section{OUR BOOK SHELF.}

De Danske Barkbiller (Scolytidae et Platypodidae Danicae). By E. A. Lövendal. Pp. xii +212 ; plates 5 . (Copenhagen, I 898 .)

IN this work Mr. Lövendal, of the Copenhagen Museum, has written a most complete account of the Danish species of bark-beetles, a subject previously dealt with by him, principally with regard to its systematic side, in Meinert's "Entomologiske Meddelelser" No European family of beetles, relatively to its size, has given rise to a more copious literature, chiefly because of its important economic relations ; and in Eichhoff"s "Die Europäischen Borkenkäfer," we possess already an excellent treatise on the European species known at the date of that work. 
While the present monograph follows, almost inevitably, the lines of Eichhoff s work, to which it constantly refers, it is, so far as its extent goes, a great advance on that book; for the author has spared no pains in achieving an exhaustive treatment of the subject, both by his own observations and by collation of what has been written by others.

Mr. Lövendal is artist as well as author, and is already well known as the illustrator of Schiödte's "De Metamorphosi Eleutheratorum." He has executed for the present work five plates, by the now almost disused method of line-engraving, which cannot be surpassed for beauty of style or accuracy of detail. The text is furnished with some eighty woodcuts, showing the burrows of these insects in bark and wood, and the whole book is printed in the most sumptuous manner.

Such a book, written entirely in Danish and on about fifty species of a single Coleopterous family, is for the very few. But it is worthy of more general examination as a monograph which in method, fulness and finish, leaves nothing to be desired. The publication of a work of this calibre would be, we fear, at present entirely beyond the resources of British entomology. W. F. H. B.

Through Arctic Lapland. By Cutcliffe Hyne. Pp.

$\mathrm{xi}+284$. (London: Adam and Charles Black, I898.)

WE have in this volume a very interesting account of the author's journey from Vardo Island, lying in the north-east corner of Norway, to Haparanda, in Sweden, situated at the head of the Gulf of Bothnia. Mr. Cutcliffe Hyne was accompanied by his friend Mr. Cecil Hayter, to whom he is indebted for the illustrations, which form an attractive feature of the book.

On arriving at Vardo, inquiries were made as to the best means of getting across the country, and it was found that the journey was an unheard-of undertaking in the summer months, the country being chiefly swamps, lakes and rivers. In winter it would have been comparatively easy, for the ground being hard, and the water frozen, there were recognised routes, and stations where relays of deer could be obtained.

However, the travellers were not to be daunted by the apparently hopeless look-out presented to them, and they persevered, with the result that they accomplished what they set out to do.

The journey is of particular interest, for this special route had never been taken before. The incidents described are numerous and exciting, and the life and customs of the nomad Lapp are well depicted. The chief means of subsistence of this Lapp is in the possession of large herds of deer; for not only does their milk, which is thick and syrupy, form part of his daily food, but he breeds them, and rears them for selling and killing. With regard to sledge-deer, it takes three years of severe training before they can safely be driven.

All through the book we are struck with the descriptions of the beauty of the vegetation, and also with the lack of wild life. The troublesome swarms of mosquitoes and flies form a special drawback for travelling in that part. Nothing of great scientific importance is disclosed, but much which will help those who wish to visit Arctic Lapland.

The New Gulliver. By Wendell Phillips Garrison.

Pp. 5I. (Jamaica, Queen sborough, New York: The Marion Press, I898.)

THIS is an amusing fantasy in which a shipwrecked graduate of Yale College is supposed to be cast upon an island, and to hold dialogues with a dapple-grey horse, which refused to acknowledge Prof. Marsh's Orohippus or Eohippus as its ancestors, and explained that there could be no moral sense without language; from which conclusion certain theological distinctions are drawn.

NO. I 523, VOL. 59]

\section{LETTERS TO THE EUITOR.}

The Editor does not hold himself responsible for opinions expresset by his correspondents. Neither can he undertake to return, or to correspond with the writers of. rejected manuscripts intended for this or any other part of NATURE. No notice is taken of anonymous communications.]

\section{Converse of the Zeeman Effect.}

I HAVE not seen it noticed that a converse action to the Zeeman effect should exist. A radiating atom in a magnetic field gives out circularly polarised light. A circularly polarised beam of light should cause a directed rotation of the electrons, so that the absorbing gas should be magnetised and exhibit magnetic force. If all the molecules in a c.c. of gas were caused to rotate their electrons in the same direction, it woulh possess quite a considerable magnetic moment. It is very im. probable that the action of a circularly polarised beam of light would control the motions to such an extent as that: but it is quite possible that, if a circularly polarised beam of sunlight were passed through a strongly absorbing gas, it would magnetise it to an observable extent. The same effect would probably exist in any medium in which absorption was principally due to syntony and not mostly due to viscous actions. Hence I would expect some effect with absorbing substances like fuchsine. It is doubtful whether lampblack, iron, or other metals have a sufficiently syntonous absorption to exhibit the effect.

My assistant Mr. Thrift is engaged in trying the experiment, but in the meanwhile I thought it might be of general interest to point out that such an effect should exist.

Geo. Fras. Fitzgeratd.

Trinity College, Dublin, December 29, 1898 .

\section{Flow of Water.}

I Took occasion, in the course of a paper on "The Character of Fluid Motion," read on December I4 before the Liverpool Engineering Society, to give the following reply, which I promised to Prof. Osborne Reynolds's letter, which appeared in your issue of September 15 last.

"Prof. Reynolds's comments may be placed under three headings :

"(I) An expression of disagreement with what he takes to be my views on the subject of the light border.

"(2) An explanation of the light border or bands adjacent to the solid boundary.

(3) The expression of the belief that the water charged with air bubbles does not in any way represent the motion of the fluid itself.

"In the first place the criticism of Prof. Reynolds is based, apparently, upon a misconception of the statement in my first paper (Trans. Inst. Naval Architects, vol. xxxix. p. I5I).

"In his letter he states as my views "that with water in sinuous motion and air bubbles as indices of the manner of motion, the light bands adjacent to the surfaces of the solids, which show absence of bubbles adjacent to the solid, prove that the once air-charged water has not been carried by sinuous motion sufficiently near to the solid surface to displace the initially adjacent water; and hence prove that the sinuous motion does not extend up to the solid surface.' What I really wrote was, however, very different to this, viz. that the result of my observations had led me to the conclusion that the "clear border line represents a condition of parallel flow of layers of water past the skin of the obstacle, or the sides of a pipe, in which a state of shearing exists, while outside this, in the darker portion, the water is in a state of sinuous motion, which corresponds to the state of the higher velocity of water.

"These two statements are really very different because it was not my own belief that the once air-charged water never reached the surface, but that when it did so, the air has been removed from it for reasons which I gave (Trans. Inst. of Naval Architects, vol. xl. p. 45), where I stated that although I had 'purposely avoided introducing unnecessary speculations in trying to account for the observed facts, it does, however, seem that the clear film may be partly accounted for as the result of inertia, which allows the heavier water to reach the side of the submerged body, and partly from the fact that the velocity being less there, the pressure might be greater, and so the air being excluded from the portion where the water is moving with 